\title{
Anti-inflammatory properties of the $\mu$ opioid receptor support its use in the treatment of colon inflammation
}

\author{
David Philippe, ${ }^{1}$ Laurent Dubuquoy, ${ }^{1}$ Hervé Groux, ${ }^{2}$ Valérie Brun, ${ }^{2}$ \\ Myriam Tran Van Chuoï-Mariot, ${ }^{3}$ Claire Gaveriaux-Ruff, Jean-Frédéric Colombel, ${ }^{4}$ \\ Brigitte L. Kieffer, ${ }^{4}$ and Pierre Desreumaux ${ }^{1}$ \\ 1Equipe Mixte INSERM 0114 sur la Physiopathologie des Maladies Inflammatoires Intestinales,
Centre Hospitalier Universitaire, Lille, France
${ }^{2}$ Unité INSERM U343, and TxCell, Hôpital de l'Archet 1, Nice, France
${ }^{3}$ Unité INSERM U422, Centre Hospitalier Universitaire, Lille, France
${ }^{4}$ Institut de Génétique et de Biologie Moléculaire et Cellulaire, UMR7104, Strasbourg, France
}

The physiologic role of the $\mu$ opioid receptor (MOR) in gut nociception, motility, and secretion is well established. To evaluate whether MOR may also be involved in controlling gut inflammation, we first showed that subcutaneous administration of selective peripheral MOR agonists, named DALDA and DAMGO, significantly reduces inflammation in two experimental models of colitis induced by administration of 2,4,6-trinitrobenzene sulfonic acid (TNBS) or peripheral expansion of $\mathrm{CD}^{+} \mathrm{T}$ cells in mice. This therapeutic effect was almost completely abolished by concomitant administration of the opioid antagonist naloxone. Evidence of a genetic role for MOR in the control of gut inflammation was provided by showing that MOR-deficient mice were highly susceptible to colon inflammation, with a $50 \%$ mortality rate occurring 3 days after TNBS administration. The mechanistic basis of these observations suggests that the anti-inflammatory effects of MOR in the colon are mediated through the regulation of cytokine production and $T$ cell proliferation, two important immunologic events required for the development of colon inflammation in mice and patients with inflammatory bowel disease (IBD). These data provide evidence that MOR plays a role in the control of gut inflammation and suggest that MOR agonists might be new therapeutic molecules in IBD.

J. Clin. Invest. 111:1329-1338 (2003). doi:10.1172/JCI200316750.

\section{Introduction}

The endogenous opioid peptide $\beta$-endorphin and opiate compounds such as morphine have well-known central and peripheral analgesic effects through activation of the $\mu$ opioid receptor (MOR) $(1,2)$. Since MOR agonists exert inhibitory effects on intestinal motility and secretion (3-5), opioids are also widely used in the symptomatic treatment of diarrhea $(6,7)$. Besides these classical therapeutic properties of opioid drugs, the demonstration of opioid peptide and MOR expression by cells involved in the inflammatory response (8-11) has led to new investigations showing the roles of MOR modulators in the regulation of the immune system and inflammatory reactions (12-17).

MOR, a member of the $G$ protein-linked receptor superfamily $(18)$, is found in the central $(19,20)$ and peripheral nervous system $(21,22)$. This receptor is

Received for publication August 26, 2002, and accepted in revised form February 26, 2003.

Address correspondence to: Pierre Desreumaux, Service de Gastroentérologie, Hôpital Huriez, Centre Hospitalier Universitaire, Lille 59037, France. Phone: 33-3-20-44-5548; Fax: 33-3-20-44-4713; E-mail: pdesreumaux@chru-lille.fr.

Conflict of interest: The authors have declared that no conflict of interest exists.

Nonstandard abbreviations used: $\mu$ opioid receptor (MOR); inflammatory bowel disease (IBD); 2,4,6-trinitrobenzene sulfonic acid (TNBS); naloxone methiodide (NM); myeloperoxidase (MPO). expressed in various tissues including the gut, particularly on lymphocytes (23) and myenteric and submucosal plexi (24). In vitro studies have shown that both opioids and naloxone, an opioid receptor antagonist, may modulate mitogen-induced PBMCs (25), splenocyte proliferation $(26,27), \mathrm{NK}$ cell activity $(28,29)$, and production of inflammatory (30-32) and immunoregulatory cytokines $(17,33-35)$. In vivo evidence of the regulatory immune functions of MOR activators has also been reported in several animal models of autoimmune $(36,37)$ and inflammatory diseases $(38-40)$.

While there is clear evidence for potential therapeutic roles of MOR ligands in the treatment of inflammatory bowel disease (IBD), the anti-inflammatory effects of selective MOR activators during intestinal inflammation remain unexplored. In the present study, we first investigated the potential effects of selective MOR agonists and one antagonist in the experimental animal model of colitis induced by intrarectal administration of 2,4,6-trinitrobenzene sulfonic acid (TNBS) (41) and by peripheral expansion of CD45RB hi $\mathrm{T}$ cells transferred into immunodeficient SCID mice (42). These two different models are well described and share many macroscopic and histologic similarities with IBD, including ulcerations, granulomas, transmural inflammation with neutrophil infiltrates, and upregulation of the TNF- $\alpha$ signaling pathway $(43,44)$. We also examined the genetic involvement of MOR in colon inflam- 
mation by studying the consequences of TNBS administration in MOR knockout $\left(\mathrm{MOR}^{-/}\right)$mice. Next, to further define the mechanistic basis of our observations, we evaluated the influence of MOR activation on the production of cytokines and expansion of $\mathrm{T}$ cells, two essential immunologic events required for the development and progression of colitis (45-48).

We describe an intestinal anti-inflammatory activity of MOR agonists and a dramatic increase of inflammation and mortality in $\mathrm{MOR}^{-/-}$mice. Experiments addressing the mechanisms for the abrogation of colitis indicate the regulatory roles of MOR on cytokine production and $\mathrm{T}$ cell proliferation. In addition to their analgesic and antidiarrheic effects, MOR agonists therefore may be an alternative to the traditional therapeutic approaches to IBD, chronic intestinal disorders characterized by inflammation, pain, and diarrhea.

\section{Methods}

The MOR agonists [D-Arg ${ }^{2}$, Lys $\left.^{4}\right]$ dermorphin-(1,4)amide (DALDA) (49) and [D-Ala ${ }^{2}, \mathrm{~N}-\mathrm{Me}-\mathrm{Phe}^{4}, \mathrm{Gly}^{5}$-ol]enkephalin (DAMGO) $(50,51)$, and the general opioid antagonist naloxone methiodide (NM) were purchased from Sigma-Aldrich (Saint Quentin Fallavier, France). TNBS was purchased from Sigma-Aldrich.

Induction of TNBS colitis and study design. Animal experiments were performed in accredited establishments at the Institut de Génétique et de Biologie Moléculaire et Cellulaire from Strasbourg and at the Institut Pasteur from Lille according to governmental guidelines. Animals were housed five per cage and had free access to standard mouse chow and tap water. For colitis induction, mice were anesthetized for 90-120 minutes and received an intrarectal administration of TNBS $(40 \mu \mathrm{l}$, $150 \mathrm{mg} / \mathrm{kg}$ ) dissolved in a $1: 1$ mixture of $0.9 \% \mathrm{NaCl}$ with $100 \%$ ethanol (41). Control mice received a 1:1 mixture of $0.9 \% \mathrm{NaCl}$ with $100 \%$ ethanol or a saline solution using the same technique. Animals were sacrificed 2 days or 4 days after TNBS administration (41). The antiinflammatory effects of MOR agonists in Balb/c mice were evaluated by administration of different dosages of DALDA $\left(10^{-3}\right.$ to $\left.1 \mathrm{mg} / \mathrm{kg} / \mathrm{d}\right)$ and DAMGO $\left(10^{-3}\right.$ to 0.5 $\mathrm{mg} / \mathrm{kg} / \mathrm{d}$ ), which selectively activate peripheral MOR and lack the ability to cross the blood-brain barrier (Figure 1) $(52,53)$. These compounds were administered once daily by subcutaneous injection, starting either 4 days before (preventive mode) or 30 minutes after (treatment mode) colitis induction. To determine whether the beneficial effects of DALDA and DAMGO were due to selective activation of peripheral MOR, the MOR antagonist NM, which does not cross the blood-brain barrier (54), was given in some mice preventively and concomitantly 6 days before colitis induction at the dose of $2.5 \mathrm{mg} / \mathrm{kg} / \mathrm{d}$ as described previously (55). Macroscopic, histological, and biological assessments of colitis were performed blindly by two investigators. In a second set of experiments, genetic evidence for the involvement of MOR in colon inflammation was evaluated by the induction of colitis in $\mathrm{MOR}^{-/-}$mice (56) that were backcrossed for ten generations onto C57BL/ 6 mice and their wild-type littermates $(9.9 \pm 0.88$ weeks of age). Due to higher susceptibility of these knockout mice to inflammation, animals were sacrificed 3 days after colitis induction.

Macroscopic and histologic assessment of TNBS-induced colitis. The colon of each mouse was examined under a dissecting microscope (magnification, $\times 5$ ) to evaluate the macroscopic lesions according to the Wallace criteria. The Wallace score rates macroscopic lesions on a scale from 0 to 10 based on features reflecting inflammation, such as hyperemia, thickening of the bowel, and extent of ulceration (57). A colon specimen located precisely 2 $\mathrm{cm}$ above the anal canal was cut into three parts. One part was fixed in $4 \%$ paraformaldehyde and embedded in paraffin. Sections stained with May-Grunwald-Giemsa were examined blindly by two investigators and scored according to the Ameho criteria (58). This grading on a scale from 0 to 6 takes into account the degree of inflammation infiltrate, the presence of erosion, ulceration, or necrosis, and the depth and surface extension of lesions (58). The other two parts of the colon were frozen and used to quantify myeloperoxidase (MPO) and mRNA of inflammatory cytokines.

Quantification of MPO. Protein preparation and immunoblotting were performed as described (59). Total protein extracts were obtained by homogenization of colon samples in a PBS lysis buffer containing $1 \%$ NP-40, $0.5 \%$ sodium deoxycholate, $0.1 \%$ SDS, and a protease inhibitor cocktail (59). Total proteins $(50 \mu \mathrm{g})$ were separated by PAGE and electroblotted (59). Immunodetection of MPO was performed after an overnight incubation of the immunoblotted membrane with a rabbit polyclonal primary antibody (dilution 1:500; DAKO Corp., Trappes, France) at $4^{\circ} \mathrm{C}$. Then a swine secondary peroxidase-conjugated antibody (dilution 1:1,000, DAKO Corp.) was added for 1 hour at room temperature. The complex was detected by chemiluminescence according to the manufacturer's protocol (ECL; Amersham Pharmacia Biotech, Orsay, France). Results were expressed as units of $O D$ per $50 \mathrm{ng}$ of total protein.

Reconstitution of SCID mice with T cell subpopulations and treatment with MOR agonists. Intestinal inflammation was induced in 6-week-old CB-17 SCID mice by intraperitoneal injection of $100 \mu \mathrm{l}$ of PBS containing $2.5 \times 10^{5}$ $\mathrm{CD}^{+} \mathrm{CD} 45 \mathrm{RB}^{\text {hi }} \mathrm{T}$ cells (44). Control of this experiment was provided by coinjection into the same mice of $1.25 \times 10^{5} \mathrm{CD}^{+}{ }^{+} \mathrm{CD} 45 \mathrm{RB}^{\text {lo }} \mathrm{T}$ cells and $2.5 \times 10^{5}$ $\mathrm{CD}^{+} \mathrm{CD}^{+} 5 \mathrm{RB}^{\text {hi }} \mathrm{T}$ cells $(44)$. These two $\mathrm{CD} 4^{+} \mathrm{T}$ cell subsets were purified from the spleens of immunocompetent mice as previously described with the following modifications $(44,60,61)$. Briefly, cells were depleted of $\mathrm{B}^{2} 20^{+}, \mathrm{Mac}^{+} 1^{+}, \mathrm{I}_{-} \mathrm{Ad}^{+}$, and $\mathrm{CD} 8^{+}$cells by negative selection using sheep anti-rat-coated antibody Dynabeads (Dynal Biotech, Oslo, Norway). The remaining cells were labeled with FITC-conjugated anti-CD45RB $(25 \mu \mathrm{g} / \mathrm{ml})$ and phycoerythrin-conjugated (PE-conjugated) anti$\mathrm{CD} 4(10 \mu \mathrm{g} / \mathrm{ml})$ and separated into $\mathrm{CD} 4{ }^{+} \mathrm{CD} 45 \mathrm{RB}^{\mathrm{hi}}$ and $\mathrm{CD} 4^{+} \mathrm{CD} 45 \mathrm{RB}^{\text {lo }}$ fractions by two-color sorting on a FACStar plus cytometer/sorter (Becton, Dickinson and 
Co., Le Pont de Claix, France). All populations were more than $98 \%$ pure on repeat analysis.

The anti-inflammatory effects of MOR agonists in CB-17 SCID mice were evaluated by subcutaneous administration of the optimal dosage of DALDA $\left(10^{-2}\right.$ $\mathrm{mg} / \mathrm{kg} / \mathrm{d})$ or DAMGO $\left(10^{-3} \mathrm{mg} / \mathrm{kg} / \mathrm{d}\right)$. These compounds were administered the day after reconstitution and continued once daily for the 4-week duration of the experiment, before mice were killed.

Clinical and microscopic examination of SCID mice. T cell-restored SCID mice were weighed weekly and sacrificed after 4 weeks. Disease development in CD45RB ${ }^{\text {hi }}$ $\mathrm{T}$ cell-reconstituted SCID mice was evaluated by analysis of weight loss and mortality rates, measurements of splenomegaly and colon thickness, and histologic assessment of the colon. For the microscopic examination, a $1-\mathrm{cm}$ piece of the distal colon was removed and embedded in paraffin. Sections were stained with MayGrunwald-Giemsa stain and graded semiquantitatively from 0 to 3 in a blinded fashion $(62,63)$. A grade of 0 was given when there were no changes observed. Changes typically associated with other grades were as follows: grade 1, minimal scattered mucosal inflammatory cell infiltrates; grade 2 , mild scattered to diffuse inflammatory cell infiltrates, sometimes extending into the submucosa and associated with erosions, with minimal to mild epithelial hyperplasia and loss of goblet cells; grade 3, massive and extensive leukocytic infiltrations that were sometimes transmural, often associated with ulceration, epithelial hyperplasia, and mucin depletion. The other parts of the distal colon were used to purify lamina propria lymphocytes and to quantify mRNA of inflammatory cytokines.

Isolation of $\mathrm{CD}^{+} \mathrm{T}$ cells from spleen and colon of $\mathrm{T}$ cell-restored SCID mice. Four weeks after T cell transfer, $\mathrm{CD}^{+}$lymphocytes were isolated from the spleen and colon as described previously, with some modification (44). Splenocytes were counted and labeled with FITCconjugated anti-CD4 and PE-conjugated anti-CD3 $(10 \mu \mathrm{g} / \mathrm{ml}$; Pharmingen, Le Pont de Claix France) and the number of CD4 ${ }^{+}$ $\mathrm{T}$ cells was determined by FACS analysis (64). For the colon, samples were washed in a solution of RPMI 1640 containing antibiotics and cut into $0.5-\mathrm{cm}$ pieces. Mucosal layers were dissected away from the muscular and serosal layers and incubated in RPMI containing $1 \mathrm{mM}$ DTT. Mucosal pieces were minced and stirred in calcium- and magnesium-free HBSS supplemented with heat-inactivated FCS (2\%) and $1 \mathrm{mM}$ EDTA. Lamina propria lymphocytes were isolated after incubating mucosal pieces with $1 \mathrm{mg} / \mathrm{ml}$ of collagenase-dispase (Sigma-Aldrich) for 90-180 minutes at $37^{\circ} \mathrm{C}$. Lymphocytes were recuperated by filtration of the supernatant and $\mathrm{CD}^{+} \mathrm{T}$ cell number was determined by FACS analysis.
Quantification of cytokines and MOR $m R N A$ in the colon. RNA was isolated from colon samples with TRIzol reagent as described (65). After treatment at $37^{\circ} \mathrm{C}$ for 30 minutes with 20-50 units of DNase I RNase-free (Roche Molecular Biochemicals, Mannheim, Germany), total RNA $(5-10 \mu \mathrm{g})$ was reverse-transcribed into cDNA. The reverse transcription reaction mixture was amplified by quantitative PCR using primers and competitors specific for $\beta$-actin, TNF- $\alpha$, IL- $1 \beta$, IL-4, and IFN- $\gamma(41,66)$. Samples and competitors were subjected to 40 PCR cycles (PE Corp., Foster City, California, USA). Quantification of cDNA was performed by electrophoresis in 3\% agarose gel using an image analyzer (Gel Analyst; Clara Vision, Paris, France) (67). The results were expressed as number of mRNA molecules per $10^{4} \mathrm{mRNA}$ molecules of an internal control, $\beta$-actin, in the same sample. MOR mRNA expression was also evaluated by RT-PCR using selected primers in proportion to a known number of $\beta$-actin mRNA molecules in the same sample (68).

Statistics. Data were expressed as mean \pm SEM. All comparisons were analyzed by the nonparametric Kruskal-Wallis one-way ANOVA test or by the MannWhitney $U$ test. Statistical analyses were performed using the StatView 4.5 statistical program (SAS Institute Inc., Meylan, France). Differences were considered significant when the $P$ value was below 0.05 .

\section{Results}

Attenuation of TNBS-induced colitis by administration of MOR agonists. First we characterized the development of colitis in animals subjected to TNBS injection. Whereas control mice sacrificed 2 days or 4 days after administration of $50 \%$ ethanol or a saline solution showed no macroscopic or histologic lesions in the colon, an acute colitis was induced as early as 2 days after TNBS administration, resulting in death in $48 \%$ of the $\mathrm{Balb} / \mathrm{c}$ mice. Four days after colitis induction, the lesions were more severe, showing necrosis of the colon and leading to
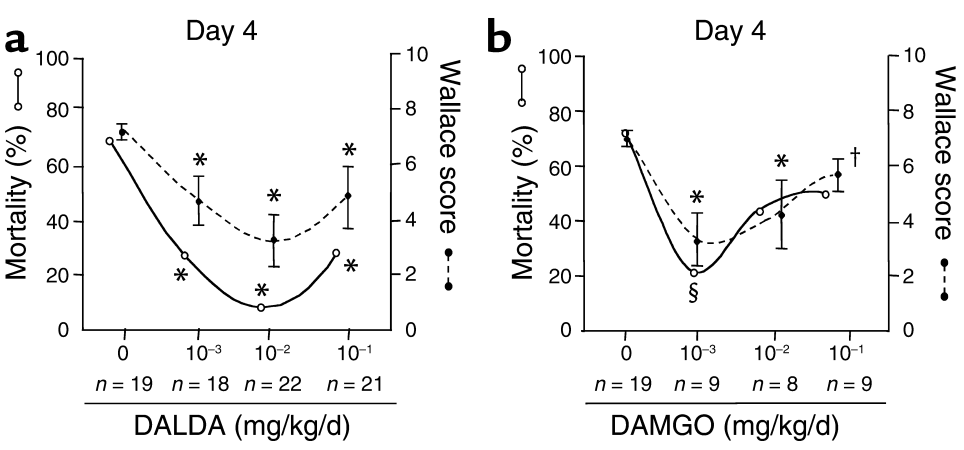

\section{Figure 1}

Dose-response study of the effects of DALDA and DAMGO on TNBS-induced colitis. The anti-inflammatory effects of different doses of DALDA (a) and DAMGO (b) given in preventive mode, once daily by subcutaneous administration, were assessed in mice sacrificed 4 days after TNBS administration. Colitis severity was evaluated by mortality rates, expressed as percentages (open circles), and by the intensity of macroscopic lesions (filled circles, mean \pm SEM), assessed using the Wallace score. The different doses of agonists and the number of mice receiving each dosage are indicated. ${ }^{*} P<0.001, \S P<0.01$, and ${ }^{\dagger} P<0.05$ in treated mice versus untreated mice with colitis. 


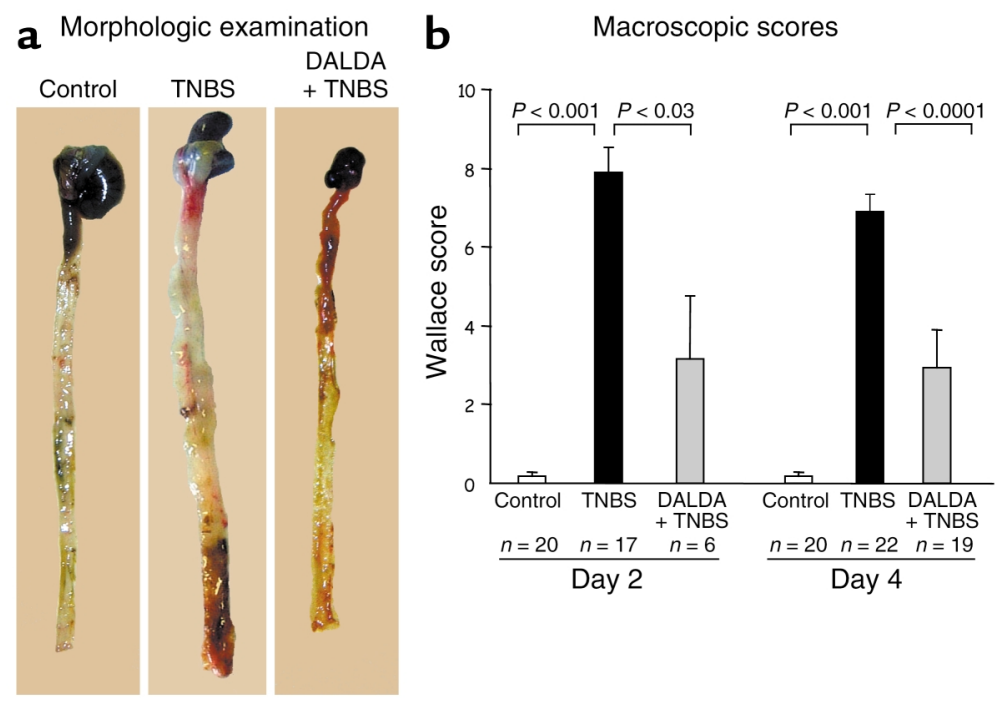

\begin{abstract}
Figure 2
DALDA improves the macroscopic lesions induced by TNBS. (a) Morphologic examination of mice receiving vehicle only (control), TNBS, or DALDA $\left(10^{-2}\right.$ $\mathrm{mg} / \mathrm{kg} / \mathrm{d}$ ) 4 days prior to the administration of TNBS (DALDA + TNBS). (b) The anti-inflammatory effects of DALDA $\left(10^{-2} \mathrm{mg} / \mathrm{kg} / \mathrm{d}\right)$ were assessed preventively 2 days (day 2) and 4 days (day 4 ) after TNBS administration. Severity of lesions was evaluated using the macroscopic Wallace score. The number of mice and statistical significance are indicated and results are expressed as mean \pm SEM.
\end{abstract}

tion, once daily until sacrifice (Figure 1). Two days and 4 days after TNBS administration, DALDA- and DAMGO-treated mice showed significantly reduced mortality compared with untreated mice with colitis, and had improved macroscopic lesions

mortality in $73 \%$ of the Balb/c mice (Figure 1 and Figure 2). TNBS-induced colitis was characterized by hyperemia of the mucosa with large areas of ulceration and thickening of the bowel wall (Figure 2). These lesions were associated with neutrophilic infiltration extending from the mucosa deep into the muscular layer and with an enhanced concentration of colon MPO, a marker of neutrophil content (69) (Figure 3).

Since DALDA and DAMGO exert their biological actions via MOR, we first verified that MOR mRNA was expressed in the healthy (MOR mRNA OD, $2.5 \pm 0.5$ measured in $10^{4} \beta$-actin molecules) colon of mice, with increased levels during inflammation (MOR mRNA $\mathrm{OD}, 5.2 \pm 1.1$ measured in $10^{4} \beta$-actin molecules, $P<0.02$ ). We then evaluated the effects of MOR activation on mortality rates and macroscopic inflammatory scores by performing a detailed dose-response study using the synthetic MOR agonists DALDA (from $10^{-3}$ to $1 \mathrm{mg} / \mathrm{kg} / \mathrm{d}$ ) and DAMGO (from $10^{-3}$ to $0.5 \mathrm{mg} / \mathrm{kg} / \mathrm{d}$ ), administered preventively 4 days before colitis induc-
(Figure 1 and Figure 2). Similar beneficial effects were seen at 2 days and 4 days after TNBS administration with the doses of $10^{-2} \mathrm{mg} / \mathrm{kg} / \mathrm{d}$ DALDA and $10^{-3}$ $\mathrm{mg} / \mathrm{kg} / \mathrm{d}$ DAMGO (Figure 1). Parallel to the gross macroscopic inflammation, histologic analysis also revealed major improvement of colitis in animals treated with DALDA compared with untreated mice (Figure 3). This was reflected by a reduction of the neutrophil infiltrate, which was limited to the mucosa, and was associated with a significant decrease of MPO levels, an absence of ulceration, and a normalization of colon wall thickness, leading to a significant decrease of the Ameho inflammatory score evaluated both at 2 days and at 4 days after TNBS administration (Figure 3).

In all the experiments described above, MOR agonists were given in preventive mode before colitis induction. We next analyzed whether the administration of DALDA after the induction of colitis was also effective in reducing the intensity of inflammation. DALDA administered after colitis induction significantly

\footnotetext{
Figure 3

DALDA improves the histologic lesions and decreases the MPO level induced by TNBS. (a-c) Histologic examination of colon sections of mice receiving vehicle only, TNBS, or $10^{-2} \mathrm{mg} / \mathrm{kg} / \mathrm{d}$ DALDA followed 4 days later by TNBS (DALDA + TNBS) (magnification, $\times 250$ ). TNBS induced severe lesions characterized by an intense inflammatory infiltrate extending deep into the colon wall with necrosis (b). Treatment with DALDA reduced the intensity of histologic inflammation, which was characterized only by a moderate inflammatory infiltrate located in the mucosa (c). (d) The histologic anti-inflammatory effects of DALDA $\left(10^{-2} \mathrm{mg} / \mathrm{kg} / \mathrm{d}\right)$ were assessed preventively 2 days and 4 days after TNBS administration. Colon MPO levels were evaluated 4 days after colitis induction. Severity of lesions was evaluated using the histologic scoring method of Ameho. The number of mice and statistical significance are indicated and results are expressed as mean \pm SEM.
}

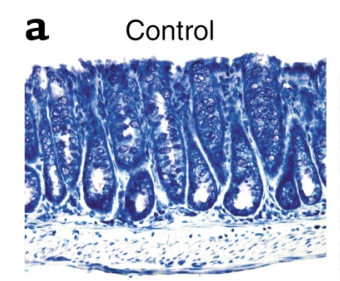

b TNBS

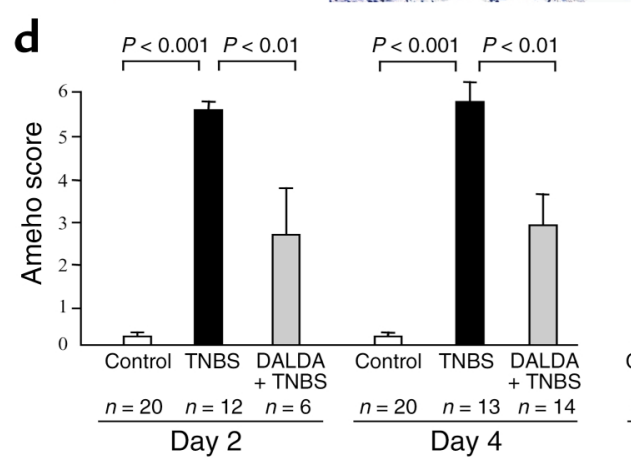

C DALDA + TNBS
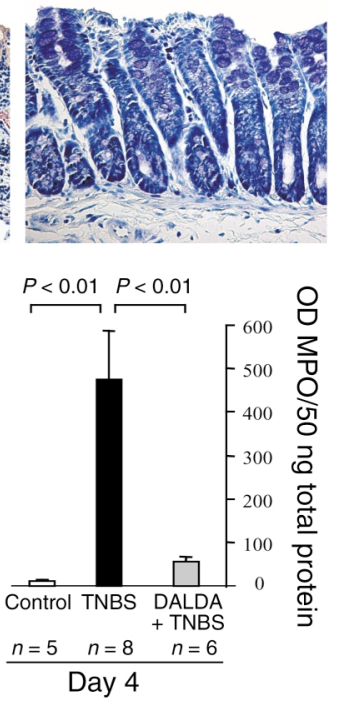


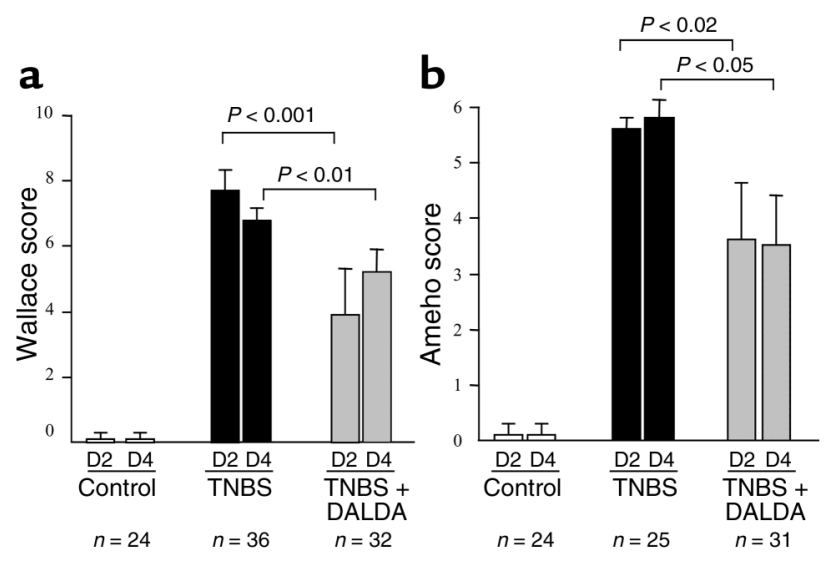

Figure 4

DALDA administered in treatment mode improves the macroscopic and histologic lesions. ( $\mathbf{a}$ and $\mathbf{b}$ ) The anti-inflammatory effects of DALDA $\left(10^{-2} \mathrm{mg} / \mathrm{kg} / \mathrm{d}\right.$ ) administered in treatment mode (after colitis induction) were assessed 2 days (D2) and 4 days (D4) after TNBS administration. The severity of the lesions was evaluated using the macroscopic and histologic scores of Wallace (a) and Ameho (b), respectively. The number of mice and statistical significance are indicated and results are expressed as the mean \pm SEM.

reduced mortality (19\% vs. $45 \%$ at day 2 and $40 \%$ vs. $73 \%$ at day 4) and macroscopic and histologic scores 2 days and 4 days after TNBS administration (Figure 4). These data demonstrate that MOR agonists can not only prevent lesion development but are also effective in reducing established inflammatory lesions in the colon.

The opioid antagonist NM abolishes the anti-inflammatory effects of DALDA. As expected, administration of NM blocked the protective effects of DALDA as shown by the similar macroscopic and histologic lesions and MPO levels found in untreated mice with colitis and mice with colitis simultaneously receiving NM and DALDA (Figure 5). Moreover, compared with untreated animals with colitis, animals administered NM alone showed increased inflammation 4 days after TNBS administration, with more numerous and deeper colon ulcerations and an enhancement of MPO levels (data not shown). Taken together, these data further confirm that the anti-inflammatory effect of DALDA is mediated by peripheral MOR activation.

Increased susceptibility of $\mathrm{MOR}^{-/-}$mice to TNBS-induced colitis. As the data from DALDA and DAMGO treatment indicate that an interaction between agonists and MOR regulates colon inflammation, we next tested whether mice homozygous for a deficiency of MOR were more susceptible to TNBS-induced colitis. $M O R^{-/-}$mice did not differ from their littermates in general health (56) (Figure 6, a-e) and had normal stools. No morphologic or histologic intestinal abnormalities were detected in $\mathrm{MOR}^{-/-}$mice compared with controls (Figure 6). Relative to Balb/c mice, TNBS induced less severe colitis in wildtype C57BL/ 6 mice, as shown by the comparison of the mortality rate and macroscopic and histologic scores (Figure 1, Figure 2, Figure 3, and Figure 6). Although no spontaneous macroscopic or histologic inflammation was found in the colon of $\mathrm{MOR}^{-/-}$mice, these knockout animals developed rapidly lethal colitis, reaching a mortality rate of $50 \% 3$ days after TNBS administration, while wild-type mice displayed 17\% mortality (Figure 6a). The lesions were severe in $\mathrm{MOR}^{-/-}$mice compared with those in control mice, involved the whole length of the colon, and were characterized by mucosal necrosis and perforation (Figure 6). In combination with the data indicating that MOR agonists significantly reduce colon inflammation, this study in $\mathrm{MOR}^{-/-}$mice demonstrates that the endogenous activation of MOR acts as a protective mechanism against intestinal inflammation.

MOR agonists prevent the development of colitis in $T$ cell-restored SCID mice. To extend the previous observation to another murine model of chronic colitis, we investigated the effects of MOR agonists on T cell-mediated immune pathology in SCID mice reconstituted with $\mathrm{CD} 4^{+} \mathrm{CD} 45 \mathrm{RB}^{\text {hi }} \mathrm{T}$ cells. As shown in Figure $7 \mathrm{a}$, the SCID mice restored with $\mathrm{CD} 4{ }^{+} \mathrm{CD} 45 \mathrm{RB}^{\text {hi }} \mathrm{T}$ cells started to lose body weight 1 week after $\mathrm{T}$ cell transfer. At the end of the experiment, CD45RB ${ }^{\text {hi }} \mathrm{T}$ cell-reconstituted SCID mice had an average body weight of $73.8 \% \pm 3.4 \%$ of their initial weight, splenomegaly with a mean fold weight increase of $4.03 \pm 0.53$ compared with control mice, intestinal inflammation characterized by edema of the small intestine (Figure 7d), and diffuse thickening and shrinkage of the colon (Figure 7e), resulting in death in $40 \%$ of the mice (Figure $7 \mathrm{~b}$ ). Histologically, lesions scored $2 \pm 0$ were characterized by epithelial hyperplasia, goblet cell depletion, and a diffuse inflammatory infiltrate mainly located in the lamina propria (Figure 8, a and c). In contrast, none of the DALDA- or DAMGOtreated CD45RB hi $T$ cell-reconstituted SCID mice had splenomegaly (Figure 7d) or inflammatory changes in the intestine (score $0.2 \pm 0.16$ ) (Figure 8 , a and d). The treated SCID mice gained weight throughout the course of the experiment without mortality and were indistinguishable from control mice reconstituted with $\mathrm{CD}^{2} 5 \mathrm{RB}^{\mathrm{hi}}$ and $\mathrm{CD} 45 \mathrm{RB}^{\text {lo }} \mathrm{T}$ cells (Figure 7 , $\mathrm{a}$ and $\mathrm{b}$ ).
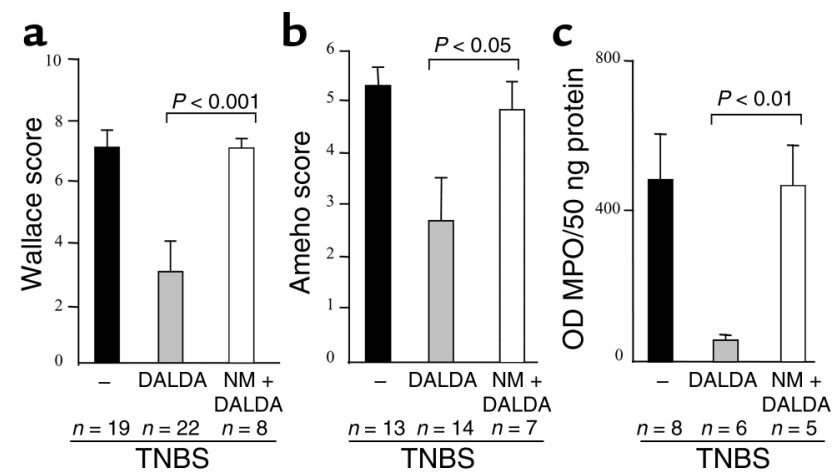

\section{Figure 5}

NM inhibits the anti-inflammatory effect of DALDA. Evaluation of (a) macroscopic and (b) histologic lesions and (c) quantification of MPO levels 4 days after TNBS administration in untreated mice (black bars) and mice receiving DALDA $\left(10^{-2} \mathrm{mg} / \mathrm{kg} / \mathrm{d}\right)$ (gray bars) or both NM and DALDA (white bars). The number of mice and statistical significance are indicated, and results are expressed as mean \pm SEM. 

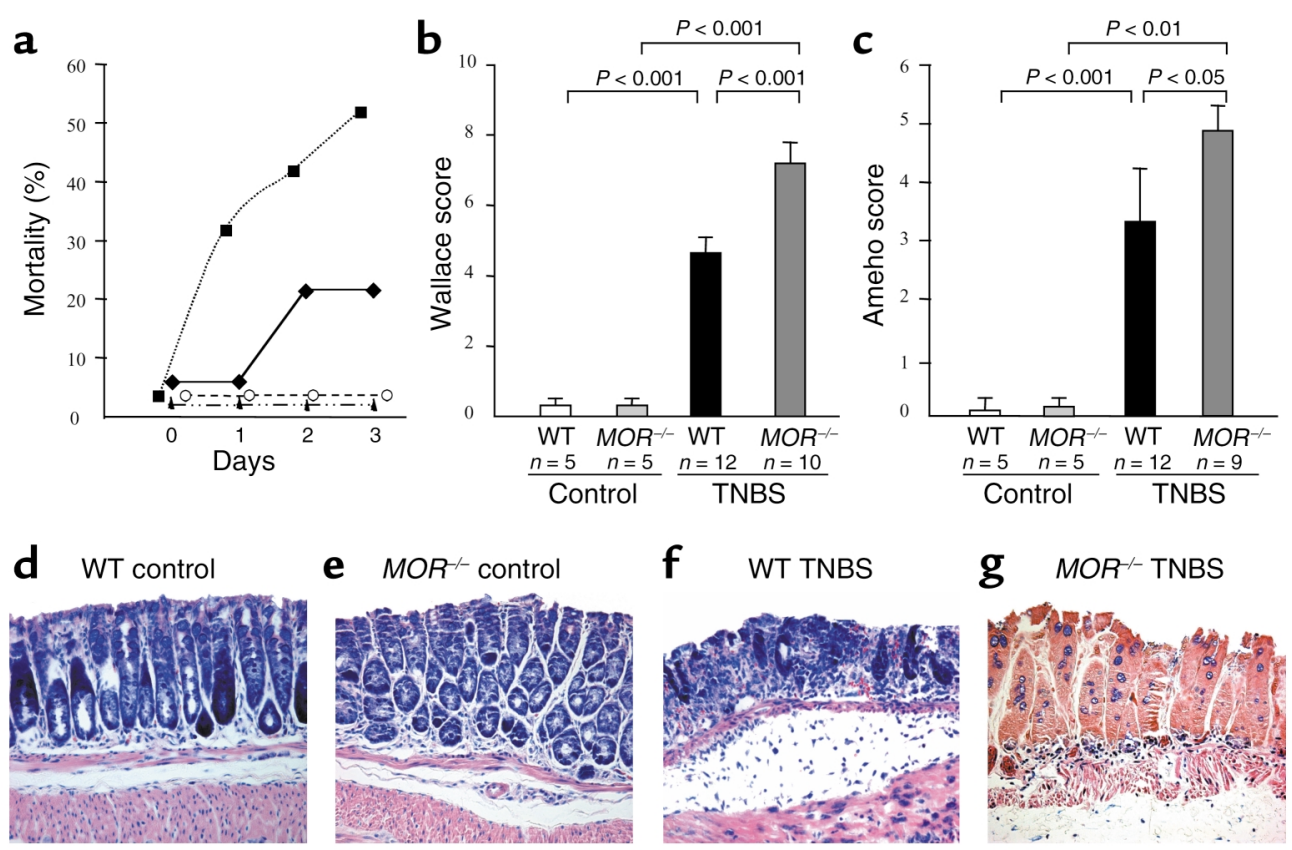

\section{Figure 6}

$\mathrm{MOR}^{-/-}$mice are more susceptible to TNBS-induced colitis. (a) Mortality rates of C57BL/ 6 wild-type and $\mathrm{MOR}^{-/-}$mice receiving vehicle (filled triangles and open circles, respectively) or TNBS (WT, filled diamonds; $M O R^{-1-}$, filled squares) daily for 3 days after TNBS administration. ( $\mathbf{b}$ and $\mathbf{c}$ ) Wallace macroscopic and Ameho histologic scores of C57BL/ 6 wild-type and MOR ${ }^{-/-}$mice 3 days after TNBS administration. The number of mice and statistical significance are indicated and results are expressed as mean \pm SEM. (d-g) Histologic examination of colon sections of wild-type and $M O R^{-/-}$mice receiving vehicle $(\mathbf{d}$ and $\mathbf{e})$ or TNBS $(\mathbf{f}$ and $\mathbf{g})(\times 250)$.

MOR agonist inhibits cytokine expression and T cell expansion. Although the above data performed in two different animal models of IBD underscore the importance of MOR activation in the regulation of colon inflammation, they do not address the possible mechanisms involved in this protective effect.

To evaluate the influence of MOR on the physiologic production of cytokines, we compared the expression of TNF- $\alpha$, IL- 4 , and IFN- $\gamma$ mRNA in the colon of mice receiving or not receiving the MOR agonist DALDA given once daily by subcutaneous administration for 8 consecutive days at a dosage of $10^{-2} \mathrm{mg} / \mathrm{kg} / \mathrm{d}$. As shown in Figure 9a, treatment with DALDA induced a significant inhibition of the basal production of TNF- $\alpha$, IL-4, and IFN- $\gamma$ mRNA in the colon. Conversely, administration of the MOR antagonist NM $(2.5 \mathrm{mg} / \mathrm{kg} / \mathrm{d}$ for 10 days) significantly increased the colon expression of these cytokines, indicating that a ligand-MOR interaction mediates the physiologic regulation of these cytokines in the colon (Figure 9a). To examine a direct relationship between MOR and cytokine expression in the colon, we compared the mRNA levels of cytokines in the colon of $\mathrm{MOR}^{-/-}$and wild-type mice. A two- to tenfold increase in the expression of TNF- $\alpha$, IL- 4 , and IFN- $\gamma$ mRNA levels was found in the colon of $\mathrm{MOR}^{-/-}$ mice compared with controls (Figure 9b). Next, we investigated the roles of MOR agonist in the modulation of inflammatory cytokine expression in the colon of mice sacrificed 4 days after TNBS administration or 4 weeks after $\mathrm{CD}^{+}{ }^{+} \mathrm{CD} 45 \mathrm{RB}^{\text {hi }} \mathrm{T}$ cell reconstitution. Low concentrations of TNF- $\alpha$ and IL-1 $\beta$ mRNA were present in the colon of control mice (Figure 9, $c$ and d). After colitis induction, colon concentrations of TNF- $\alpha$ and IL-1 $\beta$ mRNA were significantly increased, reflecting a major inflammatory reaction both in TNBS-induced colitis and in T cell-restored SCID mice (Figure 9, $\mathrm{c}$ and d). In contrast, administration of MOR agonists normalized TNF- $\alpha$ and IL- $1 \beta$ mRNA concentrations in the colon in the two experimental models of colitis (Figure 9 , c and d). Similarly, TNBS-induced colitis in $\mathrm{MOR}^{-/-}$ mice was associated with increased expression of TNF- $\alpha$ $\left(10.6 \pm 1.1\right.$ TNF- $\alpha$ mRNA molecules per $10^{4} \beta$-actin molecules) and IL-1 $\beta\left(37.9 \pm 20.3\right.$ IL- $1 \beta$ mRNA per $10^{4}$ $\beta$-actin molecules) compared with wild-type mice with colitis (respectively, $4.1 \pm 0.8$ TNF- $\alpha$ mRNA per $10^{4}$ $\beta$-actin molecules and $6.3 \pm 3.5$ IL-1 $\beta$ mRNA per $10^{4}$ $\beta$-actin molecules, $P<0.01$ ).

Since expansion of transferred $\mathrm{T}$ cells in the recipient SCID mice is also considered to play a crucial role in the pathogenesis of colitis (61), we compared the number of $\mathrm{CD}^{+} \mathrm{T}$ cells in the colon and spleen of CD45RB ${ }^{\text {hi }} \mathrm{T}$ cell-reconstituted SCID mice treated or not treated with the MOR agonist DALDA (Table 1). As shown in Table 1 , colitis was accompanied by an expansion of $\mathrm{CD} 4^{+} \mathrm{T}$ cells in the colon and spleen of untreated individual SCID mice. In DALDA-treated CD45RB hi T cell-reconstituted SCID mice, colon tissues of five mice had to be pooled to obtain quantifiable numbers of $\mathrm{CD}^{+}$cells. Table 1 shows that treatment with DALDA significantly suppressed the expansion of $\mathrm{CD} 4^{+} \mathrm{T}$ cells in the colon 

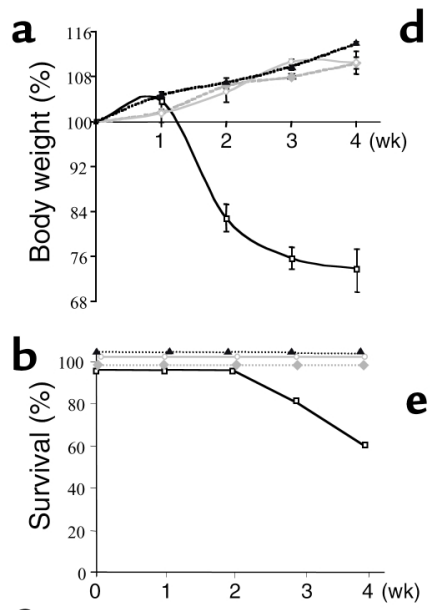

C

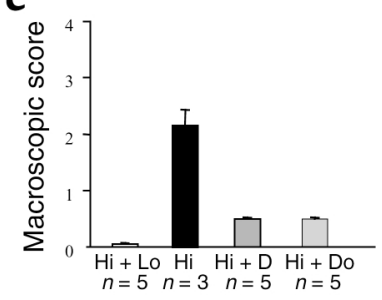

and spleen of CD45RB ${ }^{\text {hi }} \mathrm{T}$ cell-reconstituted SCID mice. Similar results were obtained when SCID mice were treated with DAMGO (data not shown).

\section{Discussion}

Many studies have documented the broad activities of MOR, particularly in the control of nociception (2), respiration $(70,71)$, cardiovascular functions $(72)$, mood (73), and gastrointestinal secretion $(3,5)$. Recently, immunomodulatory activities of endogenous and exogenous $\mu$-, $\kappa$-, and $\delta$-opioid compounds have been described, but their in vivo effects during colon inflammation remain unknown (74). In view of the high level of MOR expression in the intestinal tract, particularly during inflammation, we have analyzed the effects of two selective MOR agonists, DALDA (49) and DAMGO

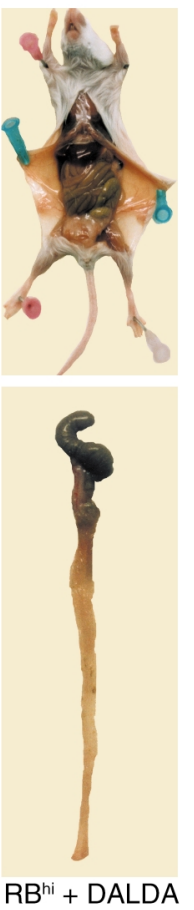

\section{Figure 7}

MOR agonists prevent wasting disease and colitis in SCID mice after $T$ cell transfer. Weekly evaluation of change in weight (mean \pm SEM) (a) and percent survival (b) in SCID mice during the 4 weeks after cell transfer. Untreated SCID mice after transfer of both $\mathrm{CD}^{+}{ }^{+} \mathrm{CD} 45 \mathrm{RB}^{\text {lo }}$ and CD45RB hi $T$ cells (diamonds) or after reconstitution with $\mathrm{CD} 4{ }^{+} \mathrm{CD} 45 \mathrm{RB}{ }^{\text {hi }} \mathrm{T}$ cells (squares). SCID mice reconstituted with $\mathrm{CD}^{+}$ CD45RB hi $T$ cells and treated with DALDA $\left(10^{-2}\right.$ $\mathrm{mg} / \mathrm{kg} / \mathrm{d}$ ) (triangles) or DAMGO $\left(10^{-3} \mathrm{mg} / \mathrm{kg} / \mathrm{d}\right.$ ) (circles). (c) Macroscopic scores (mean \pm SEM) evaluated 4 weeks after $T$ cell transfer in control SCID mice reconstituted with both $C D 4{ }^{+} C D 45 R B^{\text {lo }}$ and CD45RB hi $T$ cells $(\mathrm{Hi}+\mathrm{Lo})$ and in SCID mice with colitis reconstituted with $\mathrm{CD} 4{ }^{+} \mathrm{CD} 45 \mathrm{RB}^{\text {hi }} \mathrm{T}$ cells without any treatment $(\mathrm{Hi})$ or after subcutaneous administration of DALDA $\left(10^{-2} \mathrm{mg} / \mathrm{kg} / \mathrm{d}\right)(\mathrm{Hi}+\mathrm{D})$ or DAMGO $\left(10^{-3}\right.$ $\mathrm{mg} / \mathrm{kg} / \mathrm{d})(\mathrm{Hi}+\mathrm{Do})$. (d and $\mathbf{e})$ Representative macroscopic lesions in control SCID mice after transfer of $\mathrm{CD}^{+}{ }^{+} \mathrm{CD} 45 \mathrm{RB}^{\text {lo }}$ and CD45RB ${ }^{\text {hi }}\left(\mathrm{RB}^{\text {hi }}\right) \mathrm{T}$ cells (control) and in SCID mice with colitis after reconstitution with $\mathrm{CD}^{+} \mathrm{CD} 45 \mathrm{RB}^{\text {hi }} \mathrm{T}$ cells without any treatment $\left(\mathrm{RB}^{\mathrm{hi}}\right)$ or after subcutaneous administration of DALDA $\left(10^{-2}\right.$ $\mathrm{mg} / \mathrm{kg} / \mathrm{d})\left(\mathrm{RB}^{\mathrm{hi}}+\mathrm{DALDA}\right) . \mathrm{SM}$, splenomegaly.
(75), on intestinal inflammation induced by TNBS in mice. In this well-described and validated experimental model of colitis (41), we showed that the two MOR agonists administered before or after colitis induction by TNBS are useful for the prevention of intestinal inflammation and also provide therapeutic benefit in established inflammatory lesions of the colon. Pretreatment with NM completely abolished the protective effects of DALDA and DAMGO on intestinal inflammation, suggesting that the activity of these agonists during colitis may result from an interaction with opioid receptors. Further, our results show that $\mathrm{MOR}^{-/-}$mice are more susceptible to TNBS-induced inflammation and suggest a tonic action of MOR in the protection against colon inflammation. To extend these results to another experimental model of colitis, DALDA or DAMGO

\section{Figure 8}

MOR agonists prevent histologic colitis in reconstituted SCID mice. (a) Histologic scores (mean \pm SEM) evaluated 4 weeks after $T$ cell transfer in control SCID mice reconstituted with both $C D 4{ }^{+} \mathrm{CD} 45 \mathrm{RB}^{\text {lo }}$ and CD45RB hi T cells ( $\mathrm{Hi}+\mathrm{Lo})$ and in SCID mice with colitis reconstituted with $\mathrm{CD} 4{ }^{+} \mathrm{CD} 45 \mathrm{RB} \mathrm{B}^{\text {hi }} \mathrm{T}$ cells without any treatment $(\mathrm{Hi})$ or after subcutaneous administration of DALDA $\left(10^{-2} \mathrm{mg} / \mathrm{kg} / \mathrm{d}\right)(\mathrm{Hi}+\mathrm{D})$ or DAMGO $\left(10^{-3} \mathrm{mg} / \mathrm{kg} / \mathrm{d}\right)(\mathrm{Hi}+\mathrm{Do})$. (b-d) Representative histologic sections of the colon in control SCID mice after CD4 ${ }^{+}$CD45RB ${ }^{\text {lo }}$ and CD45RB hi T cell transfer (control) (b) and in SCID mice with colitis reconstituted with $C D 4^{+} C D 45 R^{\text {hi }} T$ cells without any treatment ( $R B^{\text {hi }}$ ) (c) or after subcutaneous administration of DALDA $\left(10^{-2} \mathrm{mg} / \mathrm{kg} / \mathrm{d}\right)$ $\left(R^{h i}+D A L D A\right)(d) \cdot \times 250$.

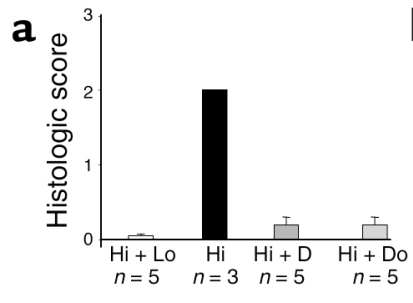

b Control

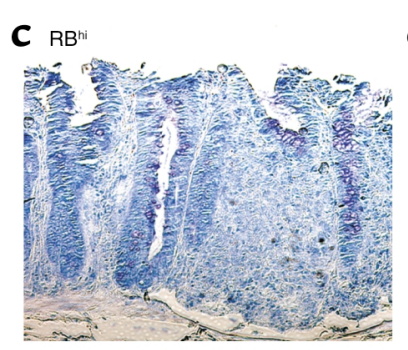

d $R B^{\text {hi }}+$ DALDA

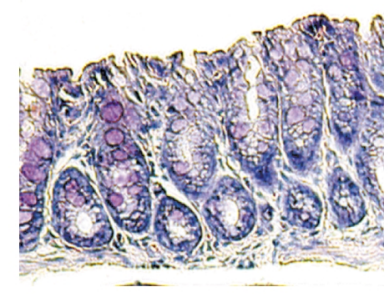



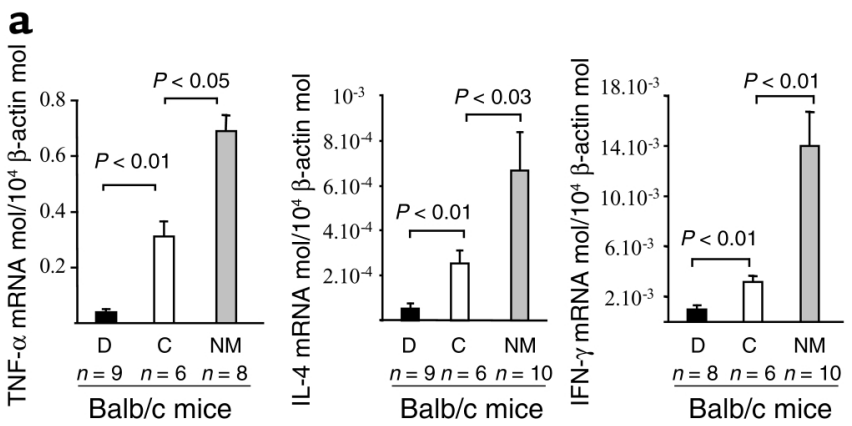

c
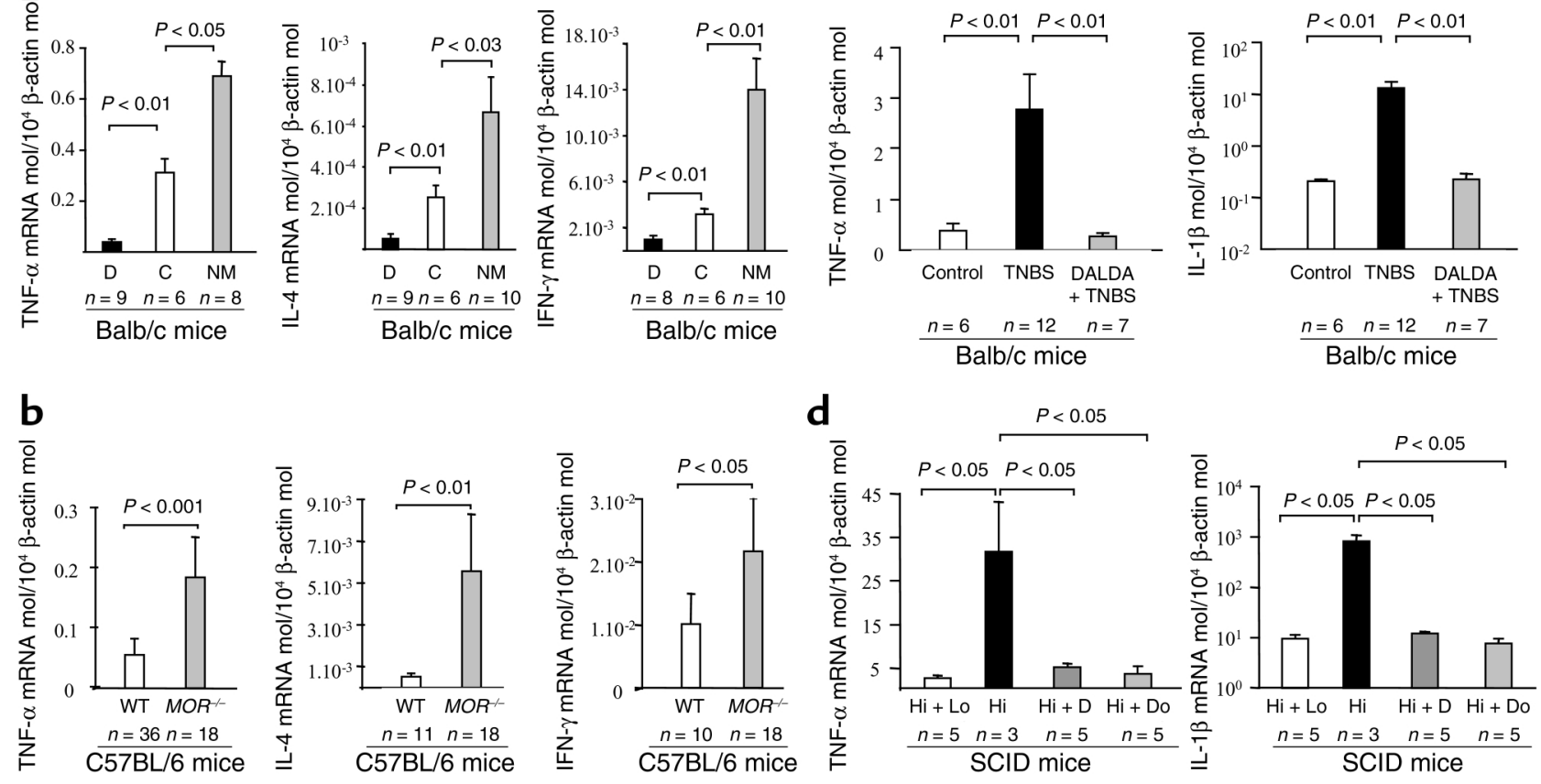

Figure 9

MOR regulates expression of inflammatory and immunoregulatory cytokines in the colon. (a and $\mathbf{b})$ Quantification of TNF- $\alpha$, IL-4, and IFN- $\gamma$ mRNA concentrations in the healthy colon of (a) Balb/c mice receiving vehicle (C) for 8 days, the MOR agonist DALDA (D) for 8 days, or the opioid antagonist NM administered subcutaneously for 10 consecutive days and in colon of (b) adult $M O R^{-/-}$mice and their wild-type littermates. (c) Quantification of inflammatory cytokine levels four days after treatment in the colon of Balb/c mice receiving vehicle only (Control), TNBS only, or DALDA followed 4 days later by TNBS. (d) Quantification of inflammatory cytokine levels in the colon 4 weeks after T cell transfer in control SCID mice reconstituted with both CD4 ${ }^{+} \mathrm{CD} 45 \mathrm{RB}^{\text {lo }}$ and CD45RB hi T cells $(\mathrm{Hi}+\mathrm{Lo})$ and in SCID mice with colitis reconstituted with $\mathrm{CD}^{+} \mathrm{CD} 45 \mathrm{RB}^{\text {hi }} \mathrm{T}$ cells without any treatment $(\mathrm{Hi})$ or after subcutaneous administration of DALDA $\left(10^{-2} \mathrm{mg} / \mathrm{kg} / \mathrm{d}\right)(\mathrm{Hi}+\mathrm{D})$ or DAMGO $\left(10^{-3} \mathrm{mg} / \mathrm{kg} / \mathrm{d}\right)(\mathrm{Hi}+\mathrm{Do})$. The number of mice and statistical significance are indicated and results are expressed as mean $\pm \mathrm{SEM}$.

was administered in SCID mice for 4 weeks after the transfer of CD45RB ${ }^{\text {hi }} \mathrm{T}$ cells. In this model of colitis dependent of $\mathrm{T}$ cell proliferation and activation, subcutaneous administration of MOR agonists effectively prevented colon inflammation, as evidenced by the absence of macroscopic and histologic lesions. Taken together, our studies with selective MOR agonists and with MOR knockout mice show that MOR might exert control of inflammatory responses in the intestine.

Numerous mechanisms may be proposed to explain the underlying anti-inflammatory effects of MOR during colitis. In the gut, the inhibitory effects of opioids on intestinal motility are believed to be mediated mainly by MOR located in the central nervous system $(76,77)$. However, since MOR is also expressed on various cells in peripheral tissues $(11,78-80)$, it may be speculated that there is a modulation of inflammation by peripheral MOR. In our study, the two selective MOR agonists, DALDA and DAMGO, and the MOR antagonist NM were selected for their inability to cross the blood-brain barrier (52-54). We therefore conclude that the protective effects of MOR during colon inflammation are probably mediated by peripheral and not central mechanisms.

Acute and chronic forms of colitis are considered to be mainly mediated by a dysregulation of inflammatory and immunoregulatory cytokine production $(16,17$,
$35,81)$ and enhanced $\mathrm{T}$ cell proliferative responses $(26$, 27). In the present study, the TNBS-induced expression of TNF- $\alpha$ and IL- $1 \beta$ mRNA in the colon was completely abolished by treatment with MOR agonists in wildtype mice and significantly enhanced in $\mathrm{MOR}^{-/-}$mice compared with their littermates. To further determine whether MOR was directly responsible for the regulation of cytokine expression in the colon, we quantified cytokines in wild-type mice without colitis that were treated with MOR agonist and in $\mathrm{MOR}^{-/-}$mice. A $30-80 \%$ inhibition of the physiologic expression of TNF- $\alpha$, IL-4, and IFN- $\gamma$ mRNA in the healthy colon of mice was observed after DALDA administration and

\section{Table 1}

Number of $\mathrm{CD} 4{ }^{+} \mathrm{CD} 45 \mathrm{RB}$ hi T cells

$\begin{array}{lcc} & \text { Spleen } & \text { Colon } \\ \mathrm{RB}^{\text {hi }}+\mathrm{RB}^{\mathrm{lo}} & 0.52 \pm 0.01 & 0.4 \pm 0.02 \\ \mathrm{RB}^{\mathrm{hi}} & 12.5 \pm 1.2 & 17.5 \pm 2.6 \\ \mathrm{RB}^{\mathrm{hi}}+\text { DALDA } & 0.55 \pm 0.05 & 0.4 \pm 0.03\end{array}$

Splenocytes and mononuclear cells that had infiltrated the spleen and colon were collected, counted, and stained with TC-conjugated anti-CD4 and PE-conjugated anti-CD3 monoclonal antibodies. Percentages of total cells represented by different cell types were analyzed by cytofluorometry and the absolute number of $\mathrm{CD} 4^{+} \mathrm{T}$ cells was calculated. Results are expressed as millions of cells per mouse. 
with a two- to fourfold increase in cytokine levels with $\mathrm{NM}$. Similar results were found in the colon of $\mathrm{MOR}^{-1-}$ mice, which spontaneously expressed more inflammatory and immunoregulatory cytokines than did their wild-type littermates. Although these results suggest that the observed modifications of cytokine expression in the mouse colon are causally related to MOR activation, they do not identify which cell populations are responsible for the MOR-dependent effects.

Colitis in SCID mice arises from proliferation of transferred $\mathrm{CD}^{+} \mathrm{T}$ cells initially in peripheral lymphoid organs such as the spleen, followed by accumulation of these cells in the intestine leading to Th1 cell-mediated chronic inflammation (82). In our study, administration of MOR agonists prevented the development of splenomegaly and inhibited the expansion of $\mathrm{CD}^{+} \mathrm{T}^{+}$ cells in the spleen and colon of CD45RB ${ }^{\text {hi }} \mathrm{T}$ cell-reconstituted SCID mice. Based on these data, we propose that the anti-inflammatory effects of MOR in the colon are mediated at least in part by the regulation of cytokine expression and expansion of $\mathrm{T}$ cells, two important immunologic events required for development of colon inflammation in mice and patients with IBD (83).

In conclusion, our findings extend the understanding of the regulation of inflammation in the colon and stress that selective agonists of peripheral MOR have preventive and therapeutic intestinal anti-inflammatory effects. The property of these MOR agonists to selectively activate peripheral MOR would prevent adverse events occurring classically with morphinomimetic compounds such as euphoria, respiratory depression, sedation, nausea, and addiction (84). Moreover, the fact that MOR expression is particularly prominent in inflamed tissue compared with healthy tissue suggests that the treatment with MOR agonists may be clinically advantageous in patients with chronic inflammatory diseases characterized by multiple recurrences, such as IBD. The main therapeutic goals in patients with IBD are the control of intestinal inflammation and the treatment of the most common clinical features, i.e., abdominal pain and diarrhea. Since MOR agonists combine analgesic functions, inhibition of intestinal motility, and anti-inflammatory effects, we suggest that these compounds are promising therapeutic agents for patients with IBD.

\section{Acknowledgments}

We thank the various members of the B.L. Kieffer and H. Groux labs for discussions and suggestions, and C. Bisiaux, A. Halgand, and V. Jeronimo for their valuable technical assistance. We enjoyed the support of grants from Institut de Recherche des Maladies de l'Appareil Digestif, the Association Francois Aupetit, the Centre Hospitalier et Universitaire de Lille, and the Région Nord-Pas de Calais.

1. Stein, C., Hassan, A.H., Lehrberger, K., Giefing, J., and Yassouridis, A. 1993. Local analgesic effect of endogenous opioid peptides. Lancet. 342:321-324.

2. Zubieta, J.K., et al. 2001. Regional mu opioid receptor regulation of sensory and affective dimensions of pain. Science. 293:311-315.

3. Turnberg, L.A. 1983. Antisecretory activity of opiates in vitro and in vivo in man. Scand. J. Gastroenterol. Suppl. 84:79-83.

4. Valle, L., Puig, M.M., and Pol, O. 2000. Effects of mu-opioid receptor agonists on intestinal secretion and permeability during acute intestinal inflammation in mice. Eur. J. Pharmacol. 389:235-242.

5. Boyd, C.A. 1976. Opiates and intestinal secretion. Lancet. 2:1085.

6. Galambos, J.T., Hersh, T., Schroder, S., and Wenger, J. 1976. Loperamide: a new antidiarrheal agent in the treatment of chronic diarrhea. Gastroenterology. 70:1026-1029.

7. Sun, W.M., Read, N.W., and Verlinden, M. 1997. Effects of loperamide oxide on gastrointestinal transit time and anorectal function in patients with chronic diarrhoea and faecal incontinence. Scand. J. Gastroenterol. 32:34-38.

8. Blalock, J.E. 1998. Beta-endorphin in immune cells. Immunol. Today. 19:191-192.

9. Cabot, P.J., et al. 1997. Immune cell-derived beta-endorphin. Production, release, and control of inflammatory pain in rats. J. Clin. Invest. 100: $142-148$.

10. Madden, J.J., Whaley, W.L., and Ketelsen, D. 1998. Opiate binding sites in the cellular immune system: expression and regulation. J. Neuroimmunol. 83:57-62.

11. Chuang, T.K., et al. 1995. Mu opioid receptor gene expression in immune cells. Biochem. Biophys. Res. Commun. 216:922-930.

12. Nelson, C.J., Schneider, G.M., and Lysle, D.T. 2000. Involvement of central mu- but not delta- or kappa-opioid receptors in immunomodulation. Brain Behav. Immun. 14:170-184.

13. Stefano, G.B., et al. 1996. Opioid and opiate immunoregulatory processes. Crit. Rev. Immunol. 16:109-144.

14. Gaveriaux-Ruff, C., Matthes, H.W., Peluso, J., and Kieffer, B.L. 1998. Abolition of morphine-immunosuppression in mice lacking the mu-opioid receptor gene. Proc. Natl. Acad. Sci. U. S. A. 95:6326-6330.

15. Kraus, J., et al. 2001. Regulation of mu-opioid receptor gene transcription by interleukin- 4 and influence of an allelic variation within a STAT6 transcription factor binding site. J. Biol. Chem. 276:43901-43908.

16. Sacerdote, P., Manfredi, B., Mantegazza, P., and Panerai, A.E. 1997. Antinociceptive and immunosuppressive effects of opiate drugs: a structure-related activity study. Br. J. Pharmacol. 121:834-840.

17. Sacerdote, P., Gaspani, L., and Panerai, A.E. 2000. The opioid antagonist naloxone induces a shift from type 2 to type 1 cytokine pattern in normal and skin-grafted mice. Ann. N. Y. Acad. Sci. 917:755-763.

18. Kieffer, B.L. 1995. Recent advances in molecular recognition and signal transduction of active peptides: receptors for opioid peptides. Cell. Mol. Neurobiol. 15:615-635.

19. Mansour, A., et al. 1994. Mu, delta, and kappa opioid receptor mRNA expression in the rat CNS: an in situ hybridization study. J. Comp. Neurol. 350:412-438.

20. Mansour, A., Fox, C.A., Burke, S., Akil, H., and Watson, S.J. 1995. Immunohistochemical localization of the cloned mu opioid receptor in the rat CNS. J. Chem. Neuroanat. 8:283-305.

21. Coggeshall, R.E., Zhou, S., and Carlton, S.M. 1997. Opioid receptors on peripheral sensory axons. Brain Res. 764:126-132.

22. Sternini, C. 2001. Receptors and transmission in the brain-gut axis: potential for novel therapies. III. Mu-opioid receptors in the enteric nervous system. Am. J. Physiol. Gastrointest. Liver Physiol. 281:G8-G15.

23. McCarthy, L., Szabo, I., Nitsche, J.F., Pintar, J.E., and Rogers, T.J. 2001. Expression of functional mu-opioid receptors during T cell development. J. Neuroimmunol. 114:173-180.

24. Bagnol, D., Mansour, A., Akil, H., and Watson, S.J. 1997. Cellular localization and distribution of the cloned mu and kappa opioid receptors in rat gastrointestinal tract. Neuroscience. 81:579-591.

25. Eisenstein, T.K., and Hilburger, M.E. 1998. Opioid modulation of immune responses: effects on phagocyte and lymphoid cell populations. J. Neuroimmunol. 83:36-44.

26. Shahabi, N.A., Burtness, M.Z., and Sharp, B.M. 1991. N-acetyl-betaendorphin1-31 antagonizes the suppressive effect of beta-endorphin131 on murine splenocyte proliferation via a naloxone-resistant receptor. Biochem. Biophys. Res. Commun. 175:936-942.

27. Panerai, A.E., Manfredi, B., Granucci, F., and Sacerdote, P. 1995. The beta-endorphin inhibition of mitogen-induced splenocytes proliferation is mediated by central and peripheral paracrine/autocrine effects of the opioid. J. Neuroimmunol. 58:71-76.

28. Shavit, Y., Lewis, J.W., Terman, G.W., Gale, R.P., and Liebeskind, J.C. 1984. Opioid peptides mediate the suppressive effect of stress on natural killer cell cytotoxicity. Science. 223:188-190.

29. Carr, D.J., DeCosta, B.R., Jacobson, A.E., Rice, K.C., and Blalock, J.E. 1990. Corticotropin-releasing hormone augments natural killer cell activity through a naloxone-sensitive pathway. J. Neuroimmunol. 28:53-61.

30. Bencsics, A., Elenkov, I.J., and Vizi, E.S. 1997. Effect of morphine on lipopolysaccharide-induced tumor necrosis factor-alpha production in vivo: involvement of the sympathetic nervous system. J. Neuroimmunol. 73:1-6.

31. Moeniralam, H.S., et al. 1998. The opiate sufentanil alters the inflam- 
matory, endocrine, and metabolic responses to endotoxin in dogs. Am. J. Physiol. 275:E440-E447.

32. Roy, S., Charboneau, R.G., and Barke, R.A. 1999. Morphine synergizes with lipopolysaccharide in a chronic endotoxemia model. J. Neuroimmunol. 95:107-114.

33. Brown, S.L., and Van Epps, D.E. 1986. Opioid peptides modulate production of interferon gamma by human mononuclear cells. Cell. Immunol. 103:19-26.

34. Sacerdote, P., Manfredi, B., Gaspani, L., and Panerai, A.E. 2000. The opioid antagonist naloxone induces a shift from type 2 to type 1 cytokine pattern in BALB/cJ mice. Blood. 95:2031-2036.

35. Peterson, P.K., Molitor, T.W., and Chao, C.C. 1998. The opioid-cytokine connection. J. Neuroimmunol. 83:63-69.

36. Sacerdote, P., Lechner, O., Sidman, C., Wick, G., and Panerai, A.E. 1999. Hypothalamic beta-endorphin concentrations are decreased in animal models of autoimmune disease. Ann. N. Y. Acad. Sci. 876:305-308.

37. Sacerdote, P., Lechner, O., Sidman, C., Wick, G., and Panerai, A.E. 1999. Hypothalamic beta-endorphin concentrations are decreased in animals models of autoimmune disease. J. Neuroimmunol. 97:129-133.

38. Mousa, S.A., Zhang, Q., Sitte, N., Ji, R., and Stein, C. 2001. beta-Endorphin-containing memory-cells and mu-opioid receptors undergo transport to peripheral inflamed tissue. J. Neuroimmunol. 115:71-78.

39. Stein, C., Millan, M.J., and Herz, A. 1988. Unilateral inflammation of the hindpaw in rats as a model of prolonged noxious stimulation: alterations in behavior and nociceptive thresholds. Pharmacol. Biochem. Behav. 31:451-455.

40. Stein, C., Millan, M.J., Shippenberg, T.S., and Herz, A. 1988. Peripheral effect of fentanyl upon nociception in inflamed tissue of the rat. Neurosci. Lett. 84:225-228.

41. Desreumaux, P., et al. 2001. Attenuation of colon inflammation through activators of the retinoid $\mathrm{X}$ receptor $(\mathrm{RXR})$ /peroxisome proliferator-activated receptor gamma (PPARgamma) heterodimer. A basis for new therapeutic strategies. J. Exp. Med. 193:827-838.

42. Groux, H., et al. 1997. A CD4+ T-cell subset inhibits antigen-specific T-cell responses and prevents colitis. Nature. 389:737-742.

43. Neurath, M.F., et al. 1997. Predominant pathogenic role of tumor necrosis factor in experimental colitis in mice. Eur. J. Immunol. 27:1743-1750.

44. Powrie, F., et al. 1994. Inhibition of Th1 responses prevents inflammatory bowel disease in scid mice reconstituted with CD45RBhi CD4+ T cells. Immunity. 1:553-562.

45. Papadakis, K.A., and Targan, S.R. 2000. Role of cytokines in the pathogenesis of inflammatory bowel disease. Annu. Rev. Med. 51:289-298.

46. Probert, C.S., et al. 1996. Persistent clonal expansions of peripheral blood CD4+ lymphocytes in chronic inflammatory bowel disease. J. Immunol. 157:3183-3191.

47. Soderstrom, K., et al. 1996. Increased frequency of abnormal gamma delta $\mathrm{T}$ cells in blood of patients with inflammatory bowel diseases. J. Immunol. 156:2331-2339.

48. Giacomelli, R., et al. 1994. Increase of circulating gamma/delta T lymphocytes in the peripheral blood of patients affected by active inflammatory bowel disease. Clin. Exp. Immunol. 98:83-88.

49. Schiller, P.W., Nguyen, T.M., Chung, N.N., and Lemieux, C. 1989. Dermorphin analogues carrying an increased positive net charge in their "message" domain display extremely high mu opioid receptor selectivity. J. Med. Chem. 32:698-703.

50. Handa, B.K., et al. 1981. Analogues of beta-LPH61-64 possessing selective agonist activity at mu-opiate receptors. Eur. J. Pharmacol. 70:531-540.

51. Kosterlitz, H.W., and Paterson, S.J. 1981. Tyr-D-Ala-Gly-MePhe-Gly-ol is a selective ligand for the $\mu$-opiate binding site. Br. J. Pharmacol. 73:299P. (Abstr.)

52. Samii, A., Bickel, U., Stroth, U., and Pardridge, W.M. 1994. Blood-brain barrier transport of neuropeptides: analysis with a metabolically stable dermorphin analogue. Am. J. Physiol. 267:E124-E131.

53. Masuo, Y., Wang, H., Pelaprat, D., Chi, Z.Q., and Rostene, W. 1992. Effect of brain lesions on $[3 \mathrm{H}]$ ohmefentanyl binding site densities in the rat striatum and substantia nigra. Chem. Pharm. Bull. (Tokyo). 40:2520-2524.

54. Milne, R.J., Coddington, J.M., and Gamble, G.D. 1990. Quaternary naloxone blocks morphine analgesia in spinal but not intact rats. Neurosci. Lett. 114:259-264.

55. Hong, Y., and Abbott, F.V. 1995. Peripheral opioid modulation of pain and inflammation in the formalin test. Eur. J. Pharmacol. 277:21-28.

56. Matthes, H.W., et al. 1996. Loss of morphine-induced analgesia, reward effect and withdrawal symptoms in mice lacking the mu-opioid-receptor gene. Nature. 383:819-823.

57. Wallace, J.L., MacNaughton, W.K., Morris, G.P., and Beck, P.L. 1989. Inhibition of leukotriene synthesis markedly accelerates healing in a rat model of inflammatory bowel disease. Gastroenterology. 96:29-36.

58. Ameho, C.K., et al. 1997. Prophylactic effect of dietary glutamine supplementation on interleukin 8 and tumour necrosis factor alpha pro- duction in trinitrobenzene sulphonic acid induced colitis. Gut 41:487-493.

59. Fajas, L., et al. 1997. The organization, promoter analysis, and expression of the human PPAR $\gamma$ gene. J. Biol. Chem. 272:18779-18789.

60. Powrie, F., Correa-Oliveira, R., Mauze, S., and Coffman, R.L. 1994. Regulatory interactions between CD45RBhigh and CD45RBlow CD4+ T cells are important for the balance between protective and pathogenic cell-mediated immunity. J. Exp. Med. 179:589-600.

61. Powrie, F., Leach, M.W., Mauze, S., Caddle, L.B., and Coffman, R.L. 1993. Phenotypically distinct subsets of CD4+ T cells induce or protect from chronic intestinal inflammation in C. B-17 scid mice. Int. Immunol. 5:1461-1471.

62. Yamamoto, M., Yoshizaki, K., Kishimoto, T., and Ito, H. 2000. IL-6 is required for the development of Th1 cell-mediated murine colitis. J. Immunol. 164:4878-4882.

63. Mackay, F., et al. 1998. Both the lymphotoxin and tumor necrosis factor pathways are involved in experimental murine models of colitis. Gastroenterology. 115:1464-1475.

64. Meresse, B., et al. 2001. CD28+ intraepithelial lymphocytes with long telomeres are recruited within the inflamed ileal mucosa in Crohn disease. Hum. Immunol. 62:694-700.

65. Desreumaux, P., et al. 1999. Inflammatory alterations in mesenteric adipose tissue in Crohn's disease. Gastroenterology. 117:73-81.

66. Müller-Alouf, H., et al. 1997. Streptococcal pyrogenic exotoxin A (SPE A) superantigen induced production of hematopoietic cytokines, IL-12 and IL-13 by human peripheral blood mononuclear cells. Microb. Pathog. 23:265-272.

67. Desreumaux, P., et al. 1997. Distinct cytokine patterns in early and chronic ileal lesions of Crohn's disease. Gastroenterology. 113:118-126.

68. Pol, O., Alameda, F., and Puig, M.M. 2001. Inflammation enhances $\mu-$ opioid receptor transcription and expression in mice intestine. Mol. Phar macol. 60:894-899.

69. Dykens, J.A., and Baginski, T.J. 1998. Urinary 8-hydroxydeoxyguanosine excretion as a non-invasive marker of neutrophil activation in animal models of inflammatory bowel disease. Scand. J. Gastroenterol. 33:628-636.

70. Gray, P.A., Rekling, J.C., Bocchiaro, C.M., and Feldman, J.L. 1999. Modulation of respiratory frequency by peptidergic input to rhythmogenic neurons in the preBotzinger complex. Science. 286:1566-1568.

71. Takita, K., Herlenius, E.A., Lindahl, S.G., and Yamamoto, Y. 1997. Actions of opioids on respiratory activity via activation of brainstem mu-, delta- and kappa-receptors; an in vitro study. Brain Res. 778:233-241.

72. Negri, L., Lattanzi, R., Tabacco, F., and Melchiorri, P. 1998. Respiratory and cardiovascular effects of the mu-opioid receptor agonist [Lys7]dermorphin in awake rats. Br. J. Pharmacol. 124:345-355.

73. Filliol, D., et al. 2000. Mice deficient for delta- and mu-opioid receptors exhibit opposing alterations of emotional responses. Nat. Genet. 25:195-200.

74. Kowalski, J. 1998. Immunomodulatory action of class mu-, delta- and kappa-opioid receptor agonists in mice. Neuropeptides. 32:301-306.

75. Kosterlitz, H.W., Paterson, S.J., and Robson, L.E. 1988. Modulation of binding at opioid receptors by mono- and divalent cations and by cholinergic compounds. J. Recept. Res. 8:363-373.

76. Tache, Y., Garrick, T., and Raybould, H. 1990. Central nervous system action of peptides to influence gastrointestinal motor function. Gastroenterology. 98:517-528.

77. Bueno, L., Fioramonti, J., Honde, C., Fargeas, M.J., and Primi, M.P. 1985. Central and peripheral control of gastrointestinal and colonic motility by endogenous opiates in conscious dogs. Gastroenterology. 88:549-556.

78. Sternini, C., et al. 1996. Agonist-selective endocytosis of mu opioid receptor by neurons in vivo. Proc. Natl. Acad. Sci. U. S. A. 93:9241-9246.

79. Makarenkova, V.P., et al. 2001. Identification of delta- and mu-type opioid receptors on human and murine dendritic cells. J. Neuroimmunol. 117:68-77.

80. Lang, M.E., Davison, J.S., Bates, S.L., and Meddings, J.B. 1996. Opioid receptors on guinea-pig intestinal crypt epithelial cells. J. Physiol. 497:161-174.

81. Roy, S., et al. 2001. Morphine directs T cells toward T(H2) differentiation. Surgery. 130:304-309.

82. Matsuda, J.L., et al. 2000. Systemic activation and antigen-driven oligoclonal expansion of $\mathrm{T}$ cells in a mouse model of colitis. J. Immunol. 164:2797-2806

83. Atreya, R., et al. 2000. Blockade of interleukin 6 trans signaling suppresses T-cell resistance against apoptosis in chronic intestinal inflammation: evidence in Crohn disease and experimental colitis in vivo. Nat. Med. 6:583-588.

84. Walker, D.J., and Zacny, J.P. 1999. Subjective, psychomotor, and physiological effects of cumulative doses of opioid mu agonists in healthy volunteers. J. Pharmacol. Exp. Ther. 289:1454-1464. 